\title{
Prezentacje
}

\section{Planetarne przebłyski}

\section{Dipesh Chakrabarty}

TEKSTY DRUGIE 2021, NR 2, S. 174-203

DOI: 10.18318/td.2021.2.11
Źródło: Dipesh

Chakrabarty, Intruduction:

Intimations of the Planetary,

[w: tegoż, The Climate

of History in a Planetary

Age, University of Chicago

Press, 2021. Drukza zgodą

wydawcy i autora.

(C) 2021 by The University

of Chicago Press. Wszelkie

prawa zastrzeżone.
Co do mnie jednak, to cały ten zamęt nie skłania mnie ani do śmiechu, ani nawet do łez, ale raczej do refleksji filozoficznej i do głębszych studiów nad naturą ludzką. Sądzę bowiem, że nie byłoby dla mnie rzeczą stosowną wyśmiewać, a tym bardziej opłakiwać naturę, skoro się zważy, że ludzie, podobnie jak wszystkie pozostałe rzeczy, są tylko cząstką przyrody, a nie jest mi wiadome, w jaki sposób dochodzi do uzgodnienia każdej części przyrody z jej całością ani jakie są jej więzi z pozostałymi częściami.

Baruch Spinoza do Henryka Oldenburga (1665) ${ }^{1}$

Gdyby Hegel, zdeklarowany miłośnik Spinozy, mógł się zagłębić w ducha naszej współczesności, dostrzegłby, że coś przesiąka - subtelnie, acz nieubłaganie - w potoczną

1 Spinoza Listy mężów uczonych do Benedykta de Spinozy oraz odpowiedzi autora wielce pomocne dla wyjaśnienia jego dzieł, przeł. L. Kołakowski, PWN, Warszawa 1961, s. 156.

\section{Dipesh Chakrabarty}

- profesor historii na Uniwersytecie w Chicago. Zajmuje się teorią postkolonialną, historią południowej Azji, historią środowiskową oraz skutkami globalnego ocieplenia. Autor książek: Rethinking Working-Class History: Bengal 1890-1940 (1989), Prowincjalizacja Europy. Myśl postkolonialna i różnica krytyczna (2000, wyd. polskie 2011), Habitations of Modernity. Essays in the Wake of Subaltern Studies (2002), The Climate of History in a Planetary Age (2021). 
świadomość historyczną konsumentów codziennej diety informacyjnej. Chodzi o żywe poczucie planety i jej historii geobiologicznej. Nie dzieje się to wszędzie w tym samym tempie, jako że globalny świat pozostaje niezaprzeczalnie nierówny. Obecna pandemia koronawirusa, ogólnoświatowy wzrost reżimów autorytarnych, rasistowskich i ksenofobicznych, a także dyskusje o energii odnawialnej, paliwach kopalnych, zmianie klimatu, ekstremalnych zjawiskach pogodowych, wyczerpywaniu się wody, utracie bioróżnorodności, antropocenie itp. - wszystko to są dla nas sygnały, choćby mgliste, że z naszą planetą dzieje się coś niedobrego i że może to mieć jakiś związek z ludzkim działaniem. Wydarzenia geologiczne wraz z historią naturalną życia stanowiły do niedawna domenę ekspertów i specjalistów. Dziś jednak planeta, jakkolwiek niejasno odczuwana, wyłania się jako obiekt szeroko podzielanej, głębokiej troski ludzi, dołączając do bardziej znajomych obaw związanych z kapitalizmem, niesprawiedliwością i nierównościami. Pandemia Covid-19 jest najświeższą tragiczną ilustracją tego, jak poszerzające się i przyspieszające procesy globalizacji mogą uruchamiać zmiany, które oddziałują na długotrwałą historię życia na planecie ${ }^{2}$. Niniejsza książka [z której pochodzi ten fragment - przyp. tłum.] dotyczy owego wyłaniającego się obiektu-kategorii ludzkiej troski - planety - oraz tego, jak wpływa ona na znajome opowieści o globalizacji. Ten zwrot pojęciowy dokonał się w ciągu mojego życia, mam więc nadzieję, że będzie mi wybaczone, jeśli zacznę od kilku refleksji autobiograficznych.

Wychowałem się w pełnej nierówności społecznych, burzliwej i lewicującej Kalkucie lat 6o. XX wieku i - jak wielu indyjskich obywateli mojego pokolenia - nauczyłem się cenić sprawiedliwe, egalitarne społeczeństwo i go pragnąłem. Ten entuzjazm okresu dojrzewania znalazł później wyraz w mojej pracy naukowej, w której początkowo zajmowałem się historią świata pracy i związałem się z indyjskim projektem badań nad podporządkowaniem (subaltern studies), nastawionych na rozpoznawanie sprawczej roli społecznie podporządkowanych ludzi w tworzeniu ich własnej historii. Nasze myślenie pozostawało pod głębokim wpływem rozwijających się na całym świecie studiów postkolonialnych, genderowych, kulturowych, mniejszościowych, tubylczych i innych perspektyw badawczych, zaliczonych

2 Zob. mój post An era of pandemics? What is global and what is planetary about COVID-19, In the Moment (blog), "Critical Inquiry" 16 października 2020, https://critinq.wordpress. com/2020/10/16/an-era-of-pandemics-what-is-global-and-what-is-planetary-aboutcovid-19/. 
przez australijskiego badacza Kennetha Ruthvena na początku lat 9o. do "nowej humanistyki"3.

Głębokie przemiany, jakie rwący nurt globalizacji wywołał w zwyczajnym życiu indyjskiej klasy średniej, do której się zaliczałem, nie ominęły i mnie w tym czasie pracowałem na Uniwersytecie Melbourne, gdzie zajmowałem się historią i teorią społeczną. Również po przeprowadzce na Uniwersytet Chicagowski w roku 1995 nadal zaprzątały mnie wątki charakterystyczne dla walk ludowych w latach mojej młodości: kwestie praw, nowoczesności i wolności, a także przejścia do świata bardziej racjonalnego i demokratycznego niż te, które znałem. Moja książka Prowincjonalizacja Europy. Myśl postkolonialna i różnica historyczna (2000, wyd. polskie 2011) była produktem owych lat, gdy próbowałem - przy użyciu ramy postkolonialnej - rozwinąć narzędzia do zrozumienia, co antykolonialne i modernizatorskie elity w byłych krajach skolonizowanych robiły i co mogły zrobić, działając nierzadko na skrajach imperialnych europejskich tradycji intelektualnych, które były ich nieuniknionym dziedzictwem. To właśnie mogłem wnieść do dyskusji o historii globu, ukształtowanej pospołu przez europejskie imperia, antykolonialnych modernizatorów i globalny kapitał - wątek, który zdominował historię i inne dyscypliny interpretatywne w ostatnich dekadach ubiegłego wieku i na początku obecnego ${ }^{4}$.

Z początkiem stulecia wydarzyło się coś, co wymusiło na mnie zmianę perspektywy. W 2003 roku pożar buszu spustoszył Australijskie Terytorium Stołeczne. Ogień odebrał życie kilku ludziom i wielu istnieniom pozaludzkim, strawił setki domów, zniszczył wszystkie lasy i parki otaczające słynną "stolicę w buszu", Canberrę. To były miejsca, które pokochałem w czasie moich studiów doktoranckich w tym kraju. Poczucie żałoby w związku z tą tragiczną stratą pobudziło moją ciekawość odnośnie do historii tych pożarów i niebawem, w miarę jak zagłębiałem się w ich przyczyny, wieści o antropogenicznej zmianie klimatu wtargnęły w humanocentryczny świat, który dotąd zamieszkiwałem. Naukowcy twierdzili, że ludzie - miliardy ludzi i ich technologia - stali się siłą geofizyczną zdolną do tego, by w przerażający sposób zmieniać system klimatyczny planety ja ko c ało ści.

3 Beyond the disciplines: the new humanities, ed. by K. Ruthven, The Australian Academy of the Humanities, Canberra 1992.

4 Inspirujące omówienie tej tematyki zaproponowali niedawno: S. Conrad What is global history?, Princeton University Press, Princeton 2016 oraz S. Ramaswamy Terrestrial lessons: the conquest of the world as globe, University of Chicago Press, Chicago 2017. 
Dowiedziałem się również o bujnie rozwijającym się piśmiennictwie naukowym poświęconym hipotezie antropocenu, czyli koncepcji, że wpływ ludzi na planetę osiągnął skalę wymagającą zmiany chronologii geologicznej dziejów Ziemi. Chodzi o uznanie, że planeta opuściła już trwającą od około 11,7 tysiąca lat epokę holocenu i wkroczyła w okres zasługujący na nową nazwę - antropocen 5 .

W okresie mego życia liczba ludzi na Ziemi się podwoiła. Istniał więc (i wciąż istnieje) człowiek znany z humanistycznych opowieści - podmiot zdolny do walki o równość i sprawiedliwość między ludźmi, a zarazem troski o środowisko i pewne formy pozaludzkiego życia. Pojawił się też jednak ten inny człowiek, człowiek jako geologiczny czynnik sprawczy, którego historia nie mieściła się już w perspektywie ściśle humanocentrycznej (jaką oferuje większość opowieści o kapitalizmie i globalizacji). Użycie słowa „sprawczość" w wyrażeniu "geologiczny czynnik sprawczy" znacząco odbiegało od koncepcji „sprawczości” używanej i uwznioślanej przez historyków, którzy byli moimi bohaterami w latach 6o., jak E.P. Thompson czy mój nauczyciel Ranajit Guha. Nie była to autonomiczna i świadoma sprawczość z opisywanej przez nich historii społecznej, lecz sprawczość bezosobowej i nieświadomej siły geofizycznej, rezultat zbiorowej aktywności ludzi.

W kwestii antropogenicznej zmiany klimatu o wymiarze planetarnym istnieje dziś naukowy konsensus, natomiast koncepcja antropocenu jest przedmiotem intensywnej debaty zarówno w naukach ścisłych, jak i w humanistyce ${ }^{6}$. Jak to się zwykle dzieje w humanistyce, debata ta uczyniła $\mathrm{z}$ antropocenu kategorię tyleż popularną, co wieloznaczną. Niezależnie jednak od tego, czy pewnego dnia geologowie uzgodnią oficjalne przyjęcie nazwy „antropocen” czy też nie, dane zgromadzone i przeanalizowane przez Grupę Roboczą ds. Antropocenu przy Międzynarodowej Komisji

5 J. Zalasiewicz et al. A general introduction to the anthropocene, w: The anthropocene as a geological time unit: a guide to the scientific evidence and current debate, ed. by J. Zalasiewicz, C.N. Waters, M. Williams, C. Summerhayes, Cambridge University Press, Cambridge 2019). Cztery inne doniosłe teksty wprowadzające do problematyki antropocenu z punktu widzenia humanistyki i nauk społecznych to: S. Lewis, M. Maslin The human planet: how we created the anthropocene, Penguin Random House, London 2018; J. Davies The birth of the anthropocene, University of California Press, Berkeley 2018); E. Horn, H. Bergthaller The anthropocene: key issues for the humanities, Routledge, London 2020; C. Merchant The anthropocene and the humanities: from climate change to a new age of sustainability, Yale University Press, New Haven 2020.

6 Niektóre z tych debat omawiam w artykule The human significance of the anthropocene, w: Modernity Reset!, ed. by B. Latour, MIT Press, Cambridge, MA 2016. 
Stratygraficznej w Londynie nie pozostawiają wątpliwości, że nie żyjemy już po prostu w epoce globalnej, lecz na progu oddzielającym to, co globalne, od tego, co można określić jako "planetarne"7. Myśląc o kilku ostatnich wiekach ludzkich przeszłości i o ludzkich przyszłościach, które dopiero nadejdą, musimy jednocześnie zwracać uwagę na to, co przywykliśmy nazywać globem, oraz na nową realność dziejowo-filozoficzną zwaną planetą. Nie jest ona tym samym co glob, kula ziemska czy świat - kategorie organizujące dotąd nasze myślenie o nowoczesnej historii. Przyspieszenie kapitalistycznej globalizacji i wynikłe stąd kryzysy globalnego ocieplenia, wraz ze wszystkimi debatami towarzyszącymi badaniu tych zjawisk, gwarantują, że planeta - czy, ściślej rzecz ujmując, system Ziemi - wkracza w orbitę naszej wiedzy, przekraczając horyzonty intelektualne wielu uczonych humanistów.

Glob, jak twierdzę, to humanocentryczny konstrukt; planeta - system Ziemi - decentruje to, co ludzkie. Podwojona liczba ludzi na Ziemi zmusza nas do przemyślenia tego, jak różne formy życia, naszego i innych, wikłają się w procesy historyczne, które wiążą ze sobą glob i planetę - i jako projektowane byty, i jako kategorie teoretyczne. W efekcie ograniczona skala czasu, w jakiej postrzegają historię nowocześni ludzie i humanistyczni historycy, miesza się z nieludzko rozległą skalą czasową „, historii głębokiej”.

\section{Kapitał, technologia i to, co planetarne}

Glob i planeta - jako kategorie reprezentujące dwie opowieści o globalizacji i globalnym ociepleniu - są ze sobą powiązane. Tym, co je łączy, są zjawiska nowoczesnego kapitalizmu (w luźnym znaczeniu tego słowa) oraz technologii - oba o zasięgu globalnym. Ostatecznie emisje gazów cieplarnianych wzrosły niemal wyłącznie wskutek dążenia do przemysłowych i poprzemysłowych form modernizacji i dobrobytu. Przy wszelkich wzajemnych krytykach między państwami nie zdarzyło się jeszcze, by jakiś kraj wzgardził tym modelem rozwoju. Dzięki rozpowszechnieniu przemysłu, jak wskazał historyk John McNeill, wiek XX stał się „okresem nadzwyczajnej zmiany” w ludzkiej historii. „Populacja ludzi wzrosła z 1,5 do 6 miliardów, światowa gospodarka wzrosła 15-krotnie, zużycie energii 13- lub 14-krotnie, zużycie wody 9-krotnie, powierzchnia objęta

7 W kwestii argumentów na temat tego, czy warto formalizować ten termin, zob. The anthropocene as a geological time unit, s. 31-40. 
nawadnianiem zaś 5-krotnie"8. Zważywszy na to powszechne dążenie do rozwoju i uprzemysłowienia, zrozumiałe jest, że zwolennicy sprawiedliwości klimatycznej postrzegają globalne ocieplenie jako rezultat kapitalistycznego nierównego rozwoju, na który trzeba patrzeć przez pryzmat relacji klasowych, rasowych i płciowych. Nic dziwnego, że patrzą oni z podejrzliwością nawet na sam temat planetarnej zmiany klimatu - jako próbę odmówienia mniej rozwiniętym narodom „przestrzeni węglowej”, której mogłyby potrzebować do rozwoju własnego przemysłu.

Sama historia kapitalizmu, tak jak ją dotąd opowiadano, nie wystarcza jednak, by objaśnić obecne położenie człowieka. Mamy bowiem do czynienia z raczkującą świadomością, że wiele z dzisiejszych katastrof „naturalnych” wynika ze zmian, jakie stworzone przez ludzi instytucje społeczno-gospodarcze i technologie wywołały w procesach określanych przez naukowców zajmujących się systemem Ziemi mianem planetarnych. Procesy te toczyły się dotąd zazwyczaj niezależnie od ludzkiej aktywności, a jednak miały zasadnicze znaczenie dla rozkwitu ludzkości i innych form życia. Im wyraźniej dostrzegamy naszą kiełkującą planetarną sprawczość, tym jaśniejsze jest, że musimy teraz myśleć o tych aspektach planety, które ludzie zwykle traktują jako oczywisty horyzont swego codziennego życia. Weźmy na przykład atmosferę i zawartość tlenu. Atmosfera jest dla naszego istnienia tak fundamentalna, jak prosty akt oddychania. Ale jaka jest historia owej atmosfery? Czy musimy wziąć tę historię pod uwagę, gdy myślimy o przyszłości ludzi? Tak, musimy. Przez ostatnie 375 milionów lat - tzn. od pojawienia się wielkich lasów - stężenie tlenu w atmosferze utrzymywane było przez określone procesy planetarne na poziomie, dzięki któremu zwierzęta nie duszą się z braku tlenu, lasy zaś nie płoną z jego nadmiaru. Różne dynamiczne procesy utrzymują atmosferę w jej obecnej równowadze. Jako że tlen jest gazem reaktywnym, powietrze potrzebuje stałych dostaw świeżego tlenu. Część tego zapotrzebowania zaspokajają drobne stworzenia żyjące w morzu, takie jak plankton. Gdyby ludzkie oddziaływanie na morze doszczętnie zniszczyło ów plankton, utracilibyśmy tym samym jedno z głównych źródeł tlenu. W skrócie, ludzie nabyli zdolność do zakłócania procesów planetarnych, niekoniecznie jednak - przynajmniej na razie - do ich naprawiania.

8 Cyt. za: A.S. Goudie, H.A. Viles Geomorphology in the anthropocene, Cambridge University Press, Cambridge 2016, s. 28. Zob. też szerszą dyskusję W: J.R. McNeill, P. Engelke The great acceleration: an environmental history of the anthropocene since 1945, Harvard University Press, Cambridge, MA 2014. 
Nasze zdolności kształtowania planety mają przeważnie naturę technologiczną, toteż technologia jest kolejną nieodzowną częścią tej rozwijającej się opowieści o ludziach. Geolog Peter Haff wprowadził niedawno pojęcie „technosfery" na określenie globalnego systemu ludzkiej technologii:

Upowszechnienie się technologii na całej kuli ziemskiej ustanawia technosferę - zestaw wielkoskalowych, usieciowionych technologii. Umożliwia ona szybkie wydobywanie z Ziemi olbrzymich ilości swobodnej energii, a w efekcie wytwarzanie mocy, niemal natychmiastową komunikację mimo przestrzennego dystansu, szybki transport energii i masy na duże odległości, istnienie nowoczesnych biurokracji rządowych (i nie tylko), działalność przemysłową i wytwórczą o wysokiej intensywności, włącznie z regionalną, kontynentalną i globalną dystrybucją żywności i innych dóbr, a także miriady dodatkowych "sztucznych” bądź „nienaturalnych" procesów, bez których nowoczesna cywilizacja i jej obecne 7 $\times 109$ ludzkich udziałowców nie mogliby istnieć. ${ }^{9}$

Zgodnie z argumentacją Haffa ludzka populacja przy jej obecnym rozmiarze jest „głęboko uzależniona od istnienia technosfery”, bez której „rychło stoczyłaby się do poziomu z czasów epoki kamienia, gdy liczyła nie więcej niż 10 milionów [...] jednostek"10. Technologia, można więc powiedzieć za Haffem, stała się warunkiem naszej biologii, warunkiem istnienia tak dużej liczby ludzi na tej planecie"1.

Teza Haffa dotycząca technosfery pozwala nam dostrzec, jak bardzo technologia stała się dziś, by posłużyć się terminem Carla Schmitta, „niezakotwiczona". Biorąc pod uwagę moc technologii, ludzie przekształcili Ziemię w statek kosmiczny dla siebie i innych form życia, których istnienie zależy od pomyślności ludzi. W swoim „Dialogu o nowej przestrzeni” z 1958 roku Schmitt posłużył się głosem fikcyjnej postaci, pana Altmana (starego historyka), aby fundamentalnie odróżnić życie na ziemi od życia na statku

9 P. Haff Technology as a geological phenomenon: implications for human well-being, w: A stratigraphical basis for the anthropocene, ed. by C.N. Waters et al., Geological Society, Special Publications, London 2014, S. 301-302. P. Haff Technology as a geological phenomenon, s. 302. in Earth system analysis: a coevolutionary perspective, "Anthropocene Review" 2017 vol. 4, no. 1, S. 23-33. 
morskim. Rdzeniem „egzystencji lądowej”, mówił, są „dom i własność, małżeństwo, rodzina i prawo dziedziczenia", a także zwierzęta - udomowione $\mathrm{i}$ inne. Technologia, gdy wkracza w tego rodzaju życie, będzie zakotwiczona w tym wszystkim, czego to życie wymaga. Technologia jako taka nigdy nie będzie nad tym życiem panować. Natomiast wraz z podbojem mórz okręt zaczął ucieleśniać to, co Schmitt nazwał „niezakotwiczoną technologią". W odróżnieniu od domu jako miejsca „egzystencji lądowej” w centrum „egzystencji morskiej” jest okręt, a więc „środek znacznie dogłębniej technologiczny niż dom". Na okręcie (tak jak teraz w samolotach) życie w decydujący sposób zależy od poprawnego działania technologii ${ }^{12}$. Gdy technologia zawodzi, życiu zagraża katastrofa. Jeśli Haff ma więc rację, twierdząc, że technosfera stała się dziś pierwotnym warunkiem przetrwania siedmiu (a wkrótce dziewięciu) miliardów ludzi, można powiedzieć, że przekształciliśmy Ziemię w coś na kształt Schmittowskiego okrętu, ponieważ jej zdolność podtrzymywania wielu miliardów żyjących istot zależy obecnie od samego istnienia technosfery. W późniejszym artykule Haff wprowadza rozróżnienie na „antropocen społeczny”, który „obejmuje położenie, motywacje i historie ziemskich społeczeństw, w tym rolę polityki” i „antropogen geologiczny”, podkreślając, iż ludzie muszą „uznać, że technosfera ma swoją sprawczość i owa sprawczość nie jest tą samą co nasza"13.

Technosfera sięga głęboko w „podziemne masy skalne przez kopalnie, odwierty i inne konstrukcje pod powierzchnią” i rozciąga się także w „królestwo morskie" - nie tylko przez statki i okręty podwodne, lecz także przez "platformy wiertnicze i rurociągi, przystanie, doki [i] instalacje akwakultury"14. Na suchym lądzie obejmuje nasze „domy, fabryki i gospodarstwa rolne" wraz z naszymi "systemami komputerowymi, smartfonami i płytami CD” oraz „odpadkami na wysypiskach śmieci i hałdach”. Technosfera ma „oszałamiającą skalę, jakieś trzydzieści bilionów ton reprezentujących masę ponad 50 kilogramów na każdy metr kwadratowy powierzchni Ziemi”. „Technosfera”, jak zauważa geolog Mark Williams, „wypączkowała z biosfery i można powiedzieć, że przynajmniej po części na niej pasożytuje". W porównaniu z biosferą

12 C. Schmitt Dialogues on power and space, ed. by A. Kalyvas, F. Finchelstein, transl. and with an introduction by S.G. Zeitlin, Polity, Cambridge 2015, s. 73-74.

13 P. Haff The technosphere and its relation to the anthropocene, w: The anthropocene as a geological time unit, s. 143 .

14 J.Zalasiewicz et al. Scale and diversity of the physical technosphere: a geological perspective, "Anthropocene Review" 2017 vol. 4, no. 1, s. 16. 
„uderzająco słabo radzi sobie ona z recyklingowaniem własnej materii, jak widać po bujnie rozrastających się wysypiskach śmieci”15.

Równie uderzające są liczby obrazujące rolę ludzi w przekształcaniu krajobrazu planety nie tylko na jej powierzchni, lecz głębiej, aż do szelfu kontynentalnego. Powierzchnia planetarna i dno morskie zostały przeobrażone przez ludzi. „Do końca XX wieku trałowanie na dnie morza odbywało się na obszarze około 15 milionów km kw. rocznie. Obecnie obejmuje to większość szelfów kontynentalnych na świecie, a także znaczne obszary górnych warstw stoku kontynentalnego oraz zbliżone do szczytu powierzchnie gór podmorskich"16. Szacuje się, że w 1994 roku „w wyniku robót ziemnych przemieszczano w skali globalnej 30 miliardów ton gleby rocznie". Szacunkowe dane z 2001 roku wskazują liczbę 57 miliardów ton rocznie. Dla porównania ilość osadów przenoszonych przez światowe rzeki do oceanów wynosi od 8,3 do 51,1 miliarda ton rocznie ${ }^{17}$. Jak stwierdza geolog Colin Waters z kolegami, ludzie „przemieszczają obecnie w ten sposób [przez górnictwo i kopalnictwo] więcej osadu niż wszystkie procesy naturalne łącznie ( $26 \mathrm{Gt} / \mathrm{rok}){ }^{\prime 18}$. Tej doniosłej roli geomorfologicznej i biologicznej nie można oddzielać od historii, która wiąże kapitalizm z globalnym ociepleniem.

Jeśli te wszystkie (i wiele innych) fakty dotyczące ludzkiego wpływu na Ziemię skłaniają naukowców do przypuszczenia, że planeta mogła już wykroczyć z epoki holocenu i wejść w zupełnie nową epokę geologiczną, to możemy powiedzieć, iż jako ludzie żyjemy dziś w dwóch odmiennych rodzajach „teraźniejszości” (tego, co Niemcy nazywają Jetztzeit) równocześnie. W naszej własnej świadomości „teraz" ludzkiej historii splotło się z długim "teraz" geologicznych i biologicznych skal czasowych - rzecz bez precedensu w dziejach ludzkości' ${ }^{19}$. To prawda, że bywały zjawiska o globalnej skali - np. trzęsienia ziemi - zdolne wtargnąć w nasze humanistyczne

University of Leicester Earth's 'technosphere' now weighs 30 trillion tons, research finds, Phys. org, 30 November 2016, https://phys.org/news/2016-11-earth-technosphere-trillion-tons. html. Podstawy tej kalkulacji przedstawiają Zalasiewicz et al. Scale and diversity of the physical technosphere, s. 9-22. A.S. Goudie, H.A. Viles Geomorphology in the anthropocene, s. 33. J. Zalasiewicz et al. The anthropocene as a geological time unit, s. 71. o zmianie klimatu i antropocenie obejmuje kwestię tego, co - pisząc ludzką historię lub politykę - zrobić z głębokim czasem. Zob. tegoż Birth of the anthropocene. 
opowieści. Niemniej przez większość czasu zdarzenia geologiczne, takie jak wyłonienie się czy erozja góry, miały charakter stopniowy, tak że góry postrzegane były jako stałe i niezmienne tło ludzkich historii. W naszych czasach uprzytomniliśmy sobie jednak, że owo tło nie jest już tylko tłem. Jesteśmy jego częścią, działając jako siła geologiczna i przyczyniając się do utraty bioróżnorodności, która może w ciągu kilkuset lat doprowadzić do szóstego wielkiego wymierania. Niezależnie od tego, czy termin „antropocen" zostanie kiedykolwiek oficjalnie przyjęty, oznacza on zakres i trwałość zmian, jakie nasz gatunek wywołuje w ziemskiej geologii, chemii i biologii ${ }^{20}$.

Myśląc o ludzkiej historii w epoce, gdy intensywna kapitalistyczna globalizacja przyniosła zagrożenie globalnym ociepleniem i masowym wymieraniem, musimy powiązać ze sobą kategorie pojęciowe, które dotąd zwykliśmy traktować jako odrębne i niemal pozbawione związku. Musimy połączyć głęboką historię z historią zapisaną, doprowadzić do spotkania czasu geologicznego i biologicznego czasu ewolucji z czasem ludzkich dziejów i doświadczenia. To zaś oznacza, że historii ludzkich imperiów - ucisku kolonialnego, rasowego i płciowego - nie można odrywać od szerszej opowieści o tym, jak pewien gatunek biologiczny, Homo sapiens, ze swoją technosferą i z innymi gatunkami, które ewoluowały wraz z nim bądź były odeń zależne, zdominował biosferę, litosferę i atmosferę tej planety. Ponadto robiąc to wszystko, nie możemy tracić z oczu pojedynczych ludzi, którzy nadal negocjują swoje własne fenomenologiczne doświadczenie życia, śmierci i świata. W tym doświadczeniu życia codziennego za oczywistość przyjmuje się „świat”, który dziś, o ironio, nie przedstawia się już jako po prostu dany ${ }^{21}$. Kryzys na poziomie planetarnym przesiąka w nasze codzienne życie w zapośredniczonych formach i, jak można sądzić, wyrasta wręcz w jakimś stopniu z decyzji podejmowanych przez nas na co dzień (takich jak latanie, jedzenie mięsa czy inne formy używania energii z paliw kopalnych). Nie oznacza to jednak, że ludzkie fenomenologiczne doświadczenie świata się przeterminowało. To prawda, nigdy nie jesteśmy oddaleni od głębokiego

20 N. Oreskes Scaling up our vision, "Isis" 2004 vol. 105, S. 388. W kwestii wielkich wymierań i tego, dlaczego stanowią one problem dla ludzkiego istnienia, zob. P.F. Sale Our dying planet: an ecologist's wiew of the crisis we face, University of California Press, Berkeley 2011, s. 102, 148-149, 203-221, 233. Zob. też E. Kolbert The sixth extinction: an unnatural history, Henry Holt, New York 2014.

21 F. Worms Pour un humanisme vital: lettres sur la vie, la mort, le moment présent, Odile Jacob, Paris 2019. 
czasu i głębokiej historii. Płyną one w naszych ciałach i w naszym życiu. W codziennej krzątaninie można zapomnieć, że jesteśmy wytworem ewolucji, ale choćby wzornictwo używanych przez nas przedmiotów zawsze będzie oparte na założeniu, że ludzi cechuje dwuoczne widzenie i mają przeciwstawne kciuki. Posiadanie dużego i złożonego mózgu może oznaczać i to, że nasza wielka, głęboka historia istnieje równolegle z naszymi małymi i powierzchownymi przeszłościami oraz poprzez nie, a nasze wewnętrzne poczucie czasu - studiowane np. przez fenomenologów - nie zawsze będzie dopasowane do chronologii ewolucyjnej i geologicznej ${ }^{22}$.

\section{Polityka na granicach polityczności}

To zbiegnięcie się ludzkiej i pozaludzkiej skali wytwarza polityczność w formie paradoksu, który wymaga zakwestionowania dotychczasowych sposobów myślenia o tej kategorii i jej używania ${ }^{23}$. Moje rozumienie słowa „polityczność" zawdzięczam myśli Hannah Arendt i lekturze Carla Schmitta. Nierozerwalny związek międzypokoleniowego czasu z Arendtowską koncepcją polityki pozwala zrozumieć, dlaczego wszelkie działania podejmowane w celu uporania się ze zmianą klimatu w okresie obejmującym czas życia wielu

W tym punkcie muszę - z szacunkiem i podziwem - odnotować drobną różnicę zdań z niektórymi tezami wysuniętymi przez Daniela Lorda Smaila w jego inspirującej książce On deep history and the brain (University of California Press, Berkeley 2008). Książkę otwiera stwierdzenie: „Jeśli ludzkość jest właściwym podmiotem historii, jak mógłby powiedzieć Linneusz, to wydaje się rozsądne, że era paleolityczna, ów długi epizod epoki kamienia przed odkryciem rolnictwa, jest częścią naszej historii" (s. 1). Z tym się zgadzam, lecz dalej Smail pisze, w odniesieniu do "bardzo starych" genów, "odpowiedzialnych za konstrukcję autonomicznego systemu nerwowego", że ich "historia jest również historią świata, ponieważ to wyposażenie jest podzielane przez wszystkich ludzi, mimo że jest rozmaicie obudowywane, manipulowane i ulepszane przez różne kultury" (s. 201). To prawda, ale właściwości fizyczne autonomicznego systemu nerwowego są czymś wspólnym dla ludzi i wielu innych zwierząt, nie może to być zatem historia tylko ludzkiego świata. Powinniśmy być może zająć się opisywaniem historii podzielanej przez różne gatunki, ale to jest już inna dyskusja. Warto jednak odnotować, że spekulacje filozofki Catherine Malabou oparte na historii ludzkiego mózgu i jego plastyczności mają duże znaczenie dla tej kwestii i jeśli przyszłe badania je potwierdzą, mogą podważyć niektóre z moich twierdzeń. C. Malabou The brain of history, or the mentality of the anthropocene , South Atlantic Quarterly" 2017 vol. 116, no. 1, s. 39-53. Zob. również tejże What should we do with our brain?, przeł. S. Rand, Fordham University Press, New York 2008.

23 Inspirujące refleksje o tym, jak antropocen koliduje z naszym nawykowym rozumieniem polityki i myśli politycznej przedstawia Duncan Kelly w książce Politics and the anthropocene (Polity, Cambridge 2019). 
pokoleń mają naturę polityczną (mimo że żadne rozwiązanie nie będzie dla wszystkich zadowalające) ${ }^{24}$.

Czytelnicy Kondycji ludzkiej pamiętają zapewne, że Arendt podkreślała ludzką zdolność wykorzystywania indywidualnych różnic - w jej słowniku wielości (plurality) - do tworzenia tego, co nowe i oryginalne w ludzkich sprawach, jako źródła „działania”., Działanie” ma fundamentalne znaczenie dla jej rozumienia polityczności i, jak pisze Arendt, „odpowiada mu ten aspekt kondycji ludzkiej, który związany jest z wielością, czyli faktem, że ludzie, a nie Człowiek, żyją na Ziemi i zamieszkują świat"25. Działanie jest „aktywnością polityczną par excellence”. Wiąże się ono również z kondycją narodzin (natality) - faktem, że każdy i każda z nas przychodzi na świat jako nowa, niepowtarzalna jednostka. „Działanie, angażując się w ustanawianie i ochronę ciał politycznych”, zauważa Arendt, „ma [...] najbliższy związek z tym aspektem kondycji ludzkiej, jakim jest przychodzenie na świat; nowy początek zawierający się w fakcie narodzin może dać się odczuć w świecie tylko dlatego, że przybysz posiada zdolność zapoczątkowania czegoś nowego, czyli działania”26. Owa możliwość nowości, to jest narodziny - „a nie

24 Zob. znakomity esej Patchena Markella poświęcony "współzależności” wytwarzania i działania: P. Markell Arendt's work: on the architecture of "The Human Condition", "College Literature" 2011 vol. 38, no. 1, s. 36-37 przyp. 3. Warto też zwrócić uwagę na następujący komentarz Miguela Vattera: „Działanie i przychodzenie na świat [...] znajdują się nawzajem w relacji «mimetycznej»: działanie może być jedynie wzmocnieniem faktu urodzenia, nigdy zaś jego ograniczeniem, kontrolą czy zdominowaniem". M. Vatter Natality and biopolitics in Hannah Arendt, „Revista de ciencia política" 2006 vol. 26, no. 2, S. 155.

H. Arendt Kondycja ludzka, przeł. A. Łagodzka, Aletheia, Warszawa 2000, s. 11, 193.

Tamże, s. 13. Ten sam argument wysuwa Arendt w Woli: „Gdyby Kant znał Augustyńską filozofię ludzkich narodzin, zgodziłby się może, że wolność, nacechowana zarazem względnq i absolutną spontanicznością, nie jest dla rozumu ludzkiego bardziej kłopotliwa niż sam fakt, że nowi ludzie pojawiają się przez na ro dziny - każdy jest nowym przybyszem w ś wi e cie, który poprzedza go w czasie". H. Arendt Wola, przeł. R. Piłat, Czytelnik, Warszawa 2002, s. 159 (wyróżnienia D.Ch.). Miguel Vatter (Natality, s. 137-159) wnikliwie omawia genezę kategorii „narodzin" i jej interpretacji w literaturze na temat Arendt. Podkreślanie znaczenia narodzin prawdopodobnie służyło Arendt do odróżnienia jej własnej myśli od Heideggerowskiej tradycji myślenia w horyzoncie śmiertelności i skończoności. Szczegółową analizę kwestii, czy przychodzenie na świat stoi w opozycji do nacisku Heideggera na skończoność i śmiertelność, czy raczej wywodzi się z Heideggerowskiego ujęcia narodzin, przedstawia Vatter (s. 138-139). Według Vattera pojęcie narodzin u Arendt ma niezależne źródła, autor ten przedstawia też bardzo interesujące obserwacje na temat związków między Arendt a Walterem Benjaminem w odniesieniu do kwestii przychodzenia na świat. Pomocne omówienie przyswajania przez Arendt koncepcji Heideggera na potrzeby jej własnej filozofii zob. D. Villa Arendt and Heidegger: the fate of the political, Princeton University Press, Princeton 1995. 
śmiertelność”, dodaje Arendt - pozostaje „centralną kategorią myśli politycznej, w odróżnieniu od metafizycznej"27. Arendt powraca do rozważań o narodzinach w późniejszych książkach z cyklu Życie umystu: „Każdy człowiek, będąc stworzony jako jednostka [w odróżnieniu od zwierząt, czyli istot gatunkowych, dopowiada Arendt], jest za sprawą swoich narodzin nowym początkiem"28. I ponownie powtarza to w Polityce jako obietnicy: „Człowiek jest apolityczny. Polityka powstaje między ludźmi, a zatem poza człow i e ki e m. Nie ma więc żadnej rzeczywistej substancji politycznej. Polityka wyłania się w tym, co zachodzi mi ęd zy ludź m i i jest ustanowione jako pewne relacje"29.

Myśl polityczna Arendt bywa krytykowana za widomy brak zainteresowania stosunkami dominacji, niesprawiedliwością, nierównościami i, co za tym idzie, demokracją ${ }^{30}$. Jednak jej koncepcja polityki odczytywana w dialogu z jej ideami na temat „działania" $i$ „wytwarzania” może dać przestrzeń pojęciową umożliwiającą dociekania właśnie nad tymi - zdaniem krytyków wzgardzonymi przez nią - kwestiami³1. Widać to wyraźnie, gdy spojrzymy na potrójne rozróżnienie - pracy, wytwarzania i działania - od którego Arendt zaczyna swoją Kondycjęludzką $a^{32}$."Aspektem kondycji ludzkiej

H. Arendt Kondycja ludzka, s. 13.

H. Arendt Wola, s. 158. Zob. też jej esej Kłamstwo w polityce: „Działanie ludzkie odznacza się tym że zawsze rozpoczyna coś nowego, co wcale nie musi znaczyć, że zawsze można je podjąć ab ovo, tworzyć ex nihilo". H. Arendt Kłamstwo w polityce. Refleksje nad "teczkami Pentagonu", przeł. P. Nowak, "Kronos" 2017 t. 42, nr 3, S. 141.

29 H. Arendt Polityka jako obietnica, przeł. W. Madej, M. Godyń, Prószyński i S-ka, Warszawa 2007, s. 126.

Zob. np. S.S. Olin Hannah Arendt: democracy and the political, "Salmagundi" 1983 no. 60, s. 3-19; H.F. Pitkin Justice: on relating private and public, "Political Theory” 1981 vol. 9, no. 3, s. 327-352; K. Breen Violence and power: a critique of Hannah Arendt on 'the political', ,Philosophy and Social Criticism" 2007 vol. 33, no. 3, s. 343-372; J. Rancière Dziesięć tez o polityce, w: tegoż Na brzegach politycznego, przeł. I. Bojadżijewa, J. Sowa, Korporacja Ha!art, Kraków 2008, s. 17-37.

1 Zob. zwłaszcza P. Markell Arendt's work. Zob. też S. Klein 'Fit to enter the world': Hannah Arendt on politics, economics, and the welfare state, "American Political Science Review” 2014 vol. 108, no. 4, s. 856-869.

Problemy wielu komentatorów z tymi rozróżnieniami syntetycznie omawia Patchen Markell w Arendt's work (s. 15-44, zob. zwłaszcza rozważania na s. 15-17). Markell wydobywa też ciekawe związki między interpretacją totalitaryzmu jako systemu pozbawiającego ludzi osobowości prawnej i sprowadzającego ich do „istot czysto przyrodniczych”, zaproponowaną przez Arendt w 1951 roku, a późniejszym opracowaniem rozróżnienia na "pracę" $i$ „wytwarzanie" (zob. s. 19). 
odpowiadającym pracy jest życie jako takie", pisze. Chodzi dosłownie o konsumpcję - metabolizm niezbędny do podtrzymania naszych biologicznych ciał oraz ich oczekiwany i nieuchronny rozkład. To, co podtrzymywane przez pracę - jednostkowe ciało - nie trwa dłużej niż czas życia jednostki. Natomiast „wytwarzanie" ma związek z wszelkiego rodzaju ludzkimi artefaktami - od języka i instytucji po wyprodukowane przedmioty - które są z konieczności międzypokoleniowe ${ }^{33}$. Wytwarzanie wytwarza „świat rzeczy”. Chociaż w tym świecie „znajduje swój dom każde jednostkowe życie”, „on sam ma przetrwać i przekraczać je wszystkie". Wytwarzanie produkuje zatem międzypokoleniowy czas jako konstytutywny dla siebie. Ideę międzypokoleniowego czasu da się streścić w argumencie, że efekty wytwarzania są trwałe, mimo że oczywiście użycie sprawia, iż owa trwałość „ulega wyczerpaniu”34. Świat, który poprzedza nas w czasie, a jednak zostawia dla nas trwałe instytucje, idee, praktyki i rzeczy, musi być nastawiony międzypokoleniowo. Arendt wiąże to z ideą zamieszkiwania: „Aby świat był tym, czym zawsze miał być, to znaczy domem ludzi żyjących na Ziemi, świat ludzkich artefaktów musi być miejscem odpowiednim dla działania i mowy"35. Aby ludzkie wytwory mogły odgrywać tę rolę, muszą przetrwać zderzenie z logiką czystej konsumpcji i użyteczności'i .

Działanie polityczne jest w tym sensie tym, co pomaga ludziom zadomowić się na Ziemi ponad granicami własnego życia. Napędzany przez konsumpcję kapitalizm, w którym wszelkie wytwory są dostępne do natychmiastowego skonsumowania, byłby antypolityczną machiną, działającą

33 „Wytwarzanie [...] wyłamuje się z cyklicznego czasu pracy: jest aktywnością, dzięki której istoty ludzkie budują świat t r wa ły c h przedmiotów" - P. Markell Arendt's work, s. 22 (wyróżnienie D.Ch.). Zob. też jego komentarze na s. 27 i 32. Wydaje mi się, że trwałość musi sięgać dalej niż czas teraźniejszy i życie jednego pokolenia, jeśli „wytwarzanie" ma zachować przypisywany mu przez Arendt charakter.

H. Arendt Kondycja ludzka, s. 152. O związkach wytwarzania i działania zob. P. Markell Arendt's work, s. 20. Idei przychodzenia na świat nie trzeba odczytywać jako argumentu na rzecz związanej z urodzeniem tożsamości. Zob. M. Vatter Natality, s. 151-152: „narodziny zasadniczo poprzedzają wspólny świat". Poniekąd zbliżoną interpretację oferuje Peg Birmingham: „[Arendt] jest nieustająco zaaferowana podwójnym cudem wydarzenia narodzin: cudem tego, co dane, i cudem początku" (P. Birmingham Hannah Arendt and human rights: the predicament of common responsibility, Indiana University Press, Bloomington 2006, s. 76). rzaniem a sztuką. Esej Markella Arendt's work stanowi ekscytujący komentarz na temat komplikacji, jakie to za sobą pociąga. 
przeciw logice ludzkiego zamieszkiwania, gdyż zamieszkiwanie wymaga artefaktów, aby trwać dłużej niż czas życia żyjących ludzi. Byłby więc pokrewny Arendtowskiej kategorii „pracy” - aktywności wspólnej dla wszystkich zwierzą zmuszonych szukać pożywienia, aby ich biologiczne życie mogło się toczyć. Kwestie związane z relacjami między pokoleniami, mimo pewnych trudności związanych z tym, że jeszcze nienarodzeni nie pojawiają się, aby przeciwstawić swoje roszczenia żądaniom żyjących, są więc podstawowe w Arendtowskim rozumieniu polityczności ${ }^{37}$.Zagadnienia sprawiedliwości klimatycznej - nie tylko między bogatymi i biednymi, lecz także między żyjącymi i nienarodzonymi - bezdyskusyjnie należą w tym ujęciu do domeny politycznej. Na tej samej zasadzie polityczne znaczenie mają pytania o to, jak ludzie mogliby się przestawić na odnawialne źródła energii, zbudować zrównoważone ekologicznie społeczeństwa itp. Nie trzeba dodawać, że takie użycie słowa „polityczny” odnosi się również do wszelkich czynności podejmowanych w celu uporania się ze skutkami globalnego ocieplenia, a tym samym z przyszłością, jaką ono tworzy, od eksperymentów naukowych, technologicznych i związanych z geoinżynierią po projektowanie polityki publicznej w różnych obszarach i aktywizm w ramach całego wachlarza dostępnych ideologii.

Uzbrojeni w tę koncepcję polityczności (wkrótce uzupełnię ją o pewne wątki Schmittowskie), stajemy wobec pytania: jak myśleć o naszych własnych czasach, gdy do postkolonialnych, postimperialnych i globalnych problemów poprzedniego stulecia dołączają takie zagadnienia, jak antropogeniczna zmiana klimatu i antropocen? Pojawienie się tych nowych tematów z pewnością nie oznacza, że sprawy, które wydawały się ważne w świecie postkolonialnym i w kontekście globalizacji, już nas nie dotyczą. Ostatecznie nadal żyjemy w czasach, gdy reprezentacja przeszłości „ludzi bez historii” jest kwestią debaty, a pytanie o suwerenność tych, którzy utracili swoje ziemie i cywilizacje na rzecz europejskich najeźdźców i okupantów, pozostaje bez odpowiedzi (i, co gorsza, odpowiedź może się okazać niemożliwa). W czasach, gdy nierówności klasowe się zaostrzają, bogactwo zaś skupia się w rękach tzw. jednego procenta, a szeregi uchodźców oraz bezpaństwowców na świecie dramatycznie rosną, podczas gdy globalny kapitał poszukuje technologii zdolnych drastycznie zmienić ludzką pracę i zagrozić jej przyszłości.

37 Imponującą, acz pesymistyczną analizę problemu międzypokoleniowej etyki i odpowiedzialności w kontekście zmiany klimatu przedstawił Stephen M. Gardiner w A perfect moral storm: the ethical tragedy of climate change (Oxford University Press, New York 2011). 
Ta sama technologia cyfrowa, której zawdzięczamy inteligentne maszyny, zyskuje Janusowe oblicze w odniesieniu do demokracji. Aplikacje i media społecznościowe takie jak WhatsApp czy Facebook moga wspierać oddolną mobilizację ludzi, ale niekoniecznie sprzyjają zniuansowanym debatom i dyskusjom, również potrzebnym w demokracji.

Rozmowa o planecie i antropocenie ma służyć nie zaprzeczaniu tym problemom, lecz wydobyciu obecnych w nich warstw, zarówno w sensie dosłownym, jak i metafo-

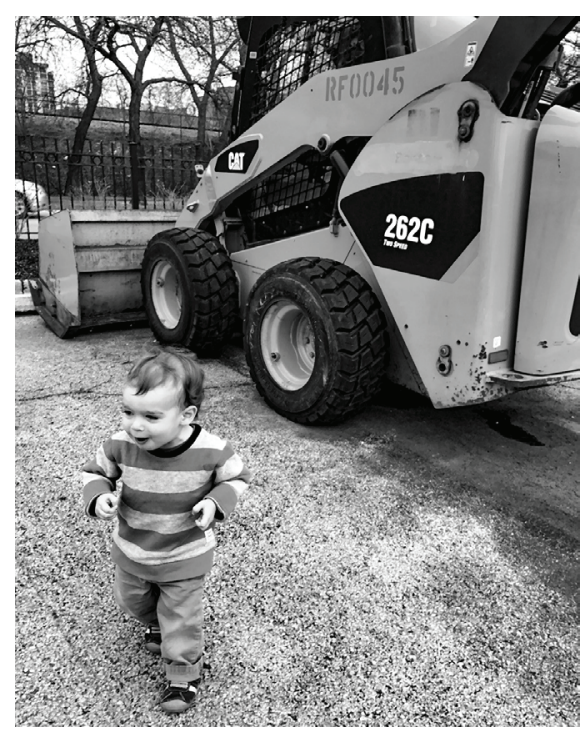

Ryc. 1. Theo, dwulatek rycznie. Geologiczny czas antropocenu i czas naszego życia codziennego w cieniu globalnego kapitału przeplatają się ze sobą. Geologia płynie przez czas ludzko-historyczny i zarazem go przekracza. Niektóre konsekwencje ludzkiego wpływu na planetę - miasta zamieniające się w wyspy upałów, wzrost częstotliwości i intensywności huraganów, zakwaszenie mórz - są dostrzegalne w czasie historycznym. Inne zaś nie - jak potencjalny wpływ antropogenicznej zmiany klimatu na cykl glacjalno-interglacjalny, który od ponad 2 milionów lat charakteryzuje dzieje naszej planety. Część efektów naszej zdolności do ingerowania w krajobraz jest widoczna i często brzydka. W indyjskim Radżastanie 31 gór, które „zniknęły” - bezprawnie zrównane z ziemią przez biznesmenów kryminalistów, poszukujących „surowców” do zaspokojenia bumu budowlanego w kraju - są szpetną demonstracją zdolności przekształcania krajobrazu przez nowoczesnych ludzi i ich maszyny ${ }^{38}$. Gdy jednak widzę w pobliskim parku dziecko bezwiednie chodzące wokół koparki,

38 Indyjska gazeta donosi, że 31 spośród 128 gór w paśmie Aravali w Radżastanie „zniknęło w ostatnim półwieczu wskutek intensywnego nielegalnego górnictwa". A.A. Choudhary $A$ fourth of Aravali Hills in Rajasthan gone forever, "Times of India”, 24 October 2018, https://timesofindia. indiatimes.com/india/31-hills-in-aravali-region-in-rajasthan-disappeared-sc-directs-stateto-stop-illegal-mining-in-48-hours/articleshow/66336416.cms. 


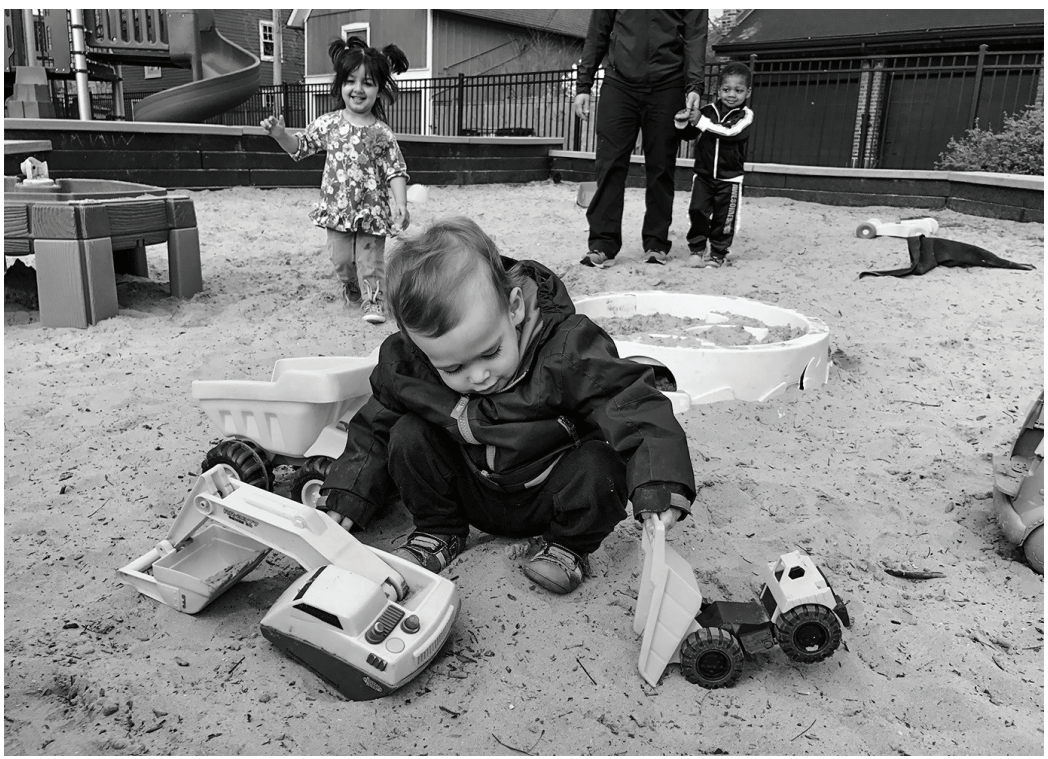

Ryc. 2. Theo i przyjaciele

a następnie to samo dziecko przerzucające piasek w piaskownicy z pomocą miniaturowej wersji tej samej maszyny - antropoceńskie zabawki! - trudno nie pomyśleć o tym, jak nasza własna sprawczość geomorfologiczna została „znaturalizowana” (Ryc. 1, 2). Nie ma mowy o sztucznym oddzieleniu czasu antropocenu od ludzkiego czasu naszego życia i historii. Nasza zdolność działania w roli siły geofizycznej na wiele sposobów wpisuje się w nowoczesne formy rozrywki.

Z kolei wiele problemów związanych z kapitalistyczną globalizacją będzie się jedynie nasilać w miarę wzrostu globalnego ocieplenia. Kurczenie się nadających się do zamieszkania obszarów planety, wzrost liczby uchodźców klimatycznych i „nielegalnych imigrantów", niedobór wody, częste ekstremalne zjawiska pogodowe, perspektywy geoinżynierii itp. - wszystko to trudno uznać za przepis na światowy pokój ${ }^{39}$. Na dodatek nasze globalne niepowo-

39 W kwestii geoinżynierii zob.: C. Hamilton Earthmasters: the dawn of the age of climate engineering, Yale University Press, New Haven 2013; D. Keith A case for climate engineering, MIT Press, Cambridge, MA 2013; and H.J. BuckAftergeoengineering: climate tragedy, repair, and restoration, Verso, London 2019. Ostrzeżenie przed możliwością ponownej barbaryzacji świata formułuje Bruno Latour w Down to Earth: politics in the new climatic regime (transl. C. Porter, Polity, Cambridge 2018). 
dzenie w stworzeniu mechanizmu zarządzania planetarną zmianą klimatu sugeruje, że nie mamy do czynienia z problemami „globalnymi” tego rodzaju, do radzenia sobie z którymi został powołany nasz ogólnoświatowy aparat zarządzania, Organizacja Narodów Zjednoczonych.

Napotykamy tu interesujący problem czasowości. Negocjacje międzynarodowe na poziomie ONZ zazwyczaj zakładają otwarty i nieokreślony kalendarz. Nie wiemy np., kiedy zapanuje pokój między państwem Izrael a ludnością palestyńską albo czy mieszkańcy Kaszmiru będą kiedykolwiek żyli w niepodzielonym kraju. To są pytania należące do otwartego i nieokreślonego kalendarza. Podobnie nie mamy pojęcia, kiedy ludziom uda się zaprowadzić uczciwy i sprawiedliwy ład na świecie. Walka przeciw kapitalizmowi zakłada, że mamy mnóstwo czasu, aby uporać się z historycznymi kwestiami niesprawiedliwości. Natomiast problem klimatyczny i dyskusje o „niebezpiecznej" zmianie klimatu konfrontują nas z określonym kalendarzem naglących działań. Mimo to potężne państwa świata usiłują poradzić sobie z tym problemem za pomocą aparatu zaprojektowanego do działań w kalendarzu otwartym. Podbudowana sukcesem protokołu montrealskiego z 1987 roku, Organizacja Narodów Zjednoczonych potraktowała zmianę klimatu jako problem "globalny", nie zaś planetarny, i próbowała go rozwiązać rutynowo. W tym celu powołano w 1988 roku Międzyrządowy Zespół ds. Zmian Klimatu (IPCC). Działania zalecane przez IPCC, np. w kwestii globalnych budżetów węglowych, zakładają jednak skończony i konkretny kalendarz, który następnie, co ciekawe, poddawany jest globalnym negocjacjom. Na przykład wartość $2^{\circ} \mathrm{C}$, postrzegana normalnie jako próg „niebezpiecznej” zmiany klimatu, stanowi politycznie wynegocjowany kompromis między ONZ-etowskim przyzwyczajeniem do nieokreślonego kalendarza a skończonym kalendarzem naukowców. Całkiem możliwe, że planetarna zmiana klimatu nie jest problemem, który organizacja taka jak ONZ mogłaby rozwiązać. Nie mamy dziś jednak lepszej demokratycznej alternatywy. Tak więc zmiana klimatu i antropocen to problemy głęboko polityczne, a zarazem podające w wątpliwość nasze zastane polityczne instytucje i wyobraźnię ${ }^{40}$.

Inspirując się myślą polityczną Arendt, warto pamiętać również o pewnej obserwacji Schmitta: chociaż ludzie potrafią być racjonalni i kreatywni, nie

D. Kelly Politics and the anthropocene; G. Mann, J. Wainwright Climate Leviathan: a political theory of our planetary future, Verso, London 2018. Omawiany tu problem czasowości wiąże się również z ideą "czasu końca", z niezwykłą starannością przeanalizowaną w: F. Hartog Chronos: L'Occident aux prises avec le temps, Collection Bibliothèque des Histoires, Gallimard, Paris 2020). 
ma czegoś takiego jak ludzkość zdolna działać jak nosiciel jednolitego racjonalnego konsensusu. „Polityczny świat”, pisze Schmitt, „to pluriwersum, nie zaś uniwersum" ${ }^{41}$. Nie wiadomo, dokąd i jaką ścieżką podąży ludzka historia. Nasze czasy wymagają przyjrzenia się pewnej kwestii, którą ani Schmitt, ani Arendt nigdy się nie zajęli. Oboje są pomocni, zapewniając nam pojemne rozumienie polityczności, ale ich spojrzenie pozostaje skupione na ludziach, a tym samym jego pojemność jest, niestety, ograniczona. Zwierzęta i inni pozaludzcy aktorzy nie mają wstępu do polityki w rozumieniu Arendt czy Schmitta. Tymczasem planetarny kryzys ekologiczny zmusza nas do rozszerzenia naszych koncepcji polityki i sprawiedliwości także na nie-ludzi, ożywionych i nieożywionych. Im bardziej oswajamy się z tą myślą, tym wyraźniej dostrzegamy, jak nieuleczalnie humanocentryczne są nasze instytucje i pojęcia polityczne. Co istotne, kryzys klimatyczny i hipoteza antropocenu łącznie stanowią dla ludzi intelektualny i polityczny kłopot, domagając się nowych interpretacji znaczenia i doniosłości tego, co kiedyś nazwałem „polityczną nowoczesnością"42. Stąd znaczenie, jakie dla tego projektu mają prace takich autorów i autorek, jak Bruno Latour, Isabelle Stenghers, Donna Haraway, Jane Bennett i innych pionierów refleksji nad rozszerzeniem granic polityczności poza świat ludzi. Poniżej odniosę się do tego problemu, bez jakichkolwiek roszczeń do jego rozwiązania.

Jak powinno być już jasne, mój wywód nie zależy w najmniejszym stopniu od tego, czy etykieta "antropocen" zostanie pewnego dnia przyjęta przez geologów jako oficjalna nazwa naszej epoki. Jak piszą Jan Zalasiewicz i jego koledzy, "przyszły status" tego terminu „jako pojęcia” może „być ogólnie uznany za pewny, ale jest niepewny w sensie oficjalnym"43. Jeremy Davies,

41 C. Schmitt Pojęcie polityczności, w: tegoż Teologia polityczna i inne pisma, przeł. M.A. Cichocki, Znak i Fundacja im. S. Batorego, Kraków-Warszawa 2000, s. 215-216, 224. W tym sensie pozostaję sceptyczny co do praktycznego wymiaru propozycji, że odpowiedzią na nienasycony popęd kapitału do akumulacji jest jakaś pojedyncza racjonalna zasada, którą wszyscy ludzie powinni zaakceptować, dobrowolnie lub nie. Zob. J. Bellamy Foster, B. Clark, R. York The ecological rift: capitalism's war on the Earth, Monthly Review Press, New York 2010, s. 417 i 436. Niejasne pozostaje dla mnie, dlaczego taki stan rzeczy, nawet uzyskany w drodze rewolucji, nie mógłby zostać rozegrany przez jakichś ludzi podążających za swym zaściankowym interesem. Ludzie, jak sądzę, skazani są na to, by pracować w realiach swoich sprzecznych interesów, pragnień, władzy i wyobraźni. przeł. D. Kołodziejczyk, T. Dobrogoszcz, E. Domańska, Wydawnictwo Poznańskie, Poznań 2011. 
Eva Horn, Hannes Bergthaller i inni słusznie wskazują, że dla humanistów największą korzyścią z debaty o antropocenie jest to, że zwróciła ona naszą uwagę na wymiar geobiologiczny. Mnie samego w szczególności zajmuje to, jak badania naukowe nad zmianą klimatu i Ziemią jako systemem wpływają na humanistów zainteresowanych problematyką czasu historycznego, który właśnie przeżywamy. Powinienem jednak zaznaczyć, że moje podejście do nauki jest dalekie od tradycji kultywowanych w niektórych nurtach studiów nad nauką, opartych - wedle słów Bernarda Williamsa - na „zdumiewającym założeniu, że socjologia wiedzy ma lepszy tytuł do wypowiedzenia prawdy o nauce niż nauka do wypowiedzenia prawdy o świecie"44. Uważam za rzecz bezdyskusyjną, że rozwój nauki pozostaje uwikłany w politykę klasy, płci, rasy, ustrojów gospodarczych i instytucji naukowych. Dlatego jak najbardziej zasadna jest podejrzliwość odnośnie do realnej władzy i autorytetu konkretnych naukowców w określonych kontekstach historycznych. Nie uważam jednak, aby tego rodzaju uwikłania sprawiały, że odkrycia w naukach przyrodniczych są bardziej arbitralne, fałszywe czy sprowadzalne do interesów politycznych niż stwierdzenia i analizy empiryczne moich kolegów uprawiających historię czy nauki społeczne ${ }^{45}$. Bez nauk nadal istniałoby ocieplenie atmosfery i występowałyby nieregularne zjawiska pogodowe, ale nie stanowiłyby one intelektualnego problemu zwanego "planetarną zmianą klimatu”, „globalnym ociepleniem" czy nawet antropocenem. Nie chodzi o to, by zaprzeczać potrzebie dwustronnej praktycznej translacji pomiędzy lokalną wiedzą, obyczajami, tradycjami i praktykami a nauką, której zasięg jest planetarny ${ }^{46}$. Trzeba jednak przyznać, że to, co „lokalne”, samo w sobie nigdy nie dałoby nam dostępu do wiedzy o roli, jaką w procesach decydujących o ochładzaniu

44 B. Williams Truth and truthfulness, Princeton University Press, Princeton 2002, s. 3. Bezpośrednim adresatem komentarza Williamsa był Bruno Latour. Uważam, że nie jest to uczciwa krytyka Latoura, ale niestety jest w tych słowach coś na rzeczy. W krytycznych studiach nad nauką zdarzyło mi się napotykać teksty, które wydają się kierować krytykowanymi przez Williamsa przesłankami.

Ostatecznie jeśli nauka nie jest niczym innym jak polityką (jakkolwiek rozumianą), to jaki jest poznawczy status samego tego stwierdzenia? Czy daje ono więcej pewności niż nauka bądź polityka?

Antropologowie często podkreślają istniejącą w wielu częściach świata praktyczno-polityczną potrzebę przekładu abstrakcyjnej wiedzy naukowej o zmianie klimatu i antropocenie na lokalnie zrozumiałe pojęcia i troski. Zob. np. S. de Wit To see or not to see: on the 'absence' of climate change (discourse) in Maasailand, Northern Tanzania oraz V. Kwashirai Perspectives on climate change in Makonde District, Zimbabwe since 2000, oba teksty w: Environmental change and African societies, ed. by I. Haltermann, J. Tischler, Brill, Leiden 2019, s. 23-47 i 48-70. 
bądź ocieplaniu całej planety odgrywają regiony słabo zaludnione lub w ogóle niezamieszkane przez ludzi, takie jak oceany czy pokryte wieczną zmarzliną obszary Syberii.

\section{Ewolucja i struktura książki}

Pod wpływem natarczywych myśli o planetarnej zmianie klimatu, a zarazem zmotywowany wyzwaniami metodologicznymi, jakie problem geologicznej sprawczości ludzi rzucił moim intelektualnym nawykom humanistycznego historyka, opublikowałem w 2009 roku esej Klimat historii. Cztery tezy ${ }^{47}$. Zastanawiałem się w nim, czym jest ludzkość w epoce antropocenu. Jesteśmy równocześnie podzieloną ludzkością i dominującym partnerem w techno-socjoekonomiczno-biologicznym kompleksie obejmującym też inne gatunki. To właśnie ten kompleks napędza wymieranie gatunków, a tym samym stanowi część dziejów życia na tej planecie. W efekcie ów kompleks jest także geologiczną siłą sprawczą. Wraz z załamaniem się wielorakich chronologii - historii gatunkowej i czasów geologicznych w obrębie żywej pamięci - kondycja ludzka się zmieniła. Zmiana ta nie oznacza, że powiązane, ale różne historie ludzi jako podzielonej ludzkości, jako gatunku i jako geologicznej siły sprawczej stopiły się teraz w jedną wielką geostorię i że owa jednolita historia planety i historii życia na planecie może zastąpić wielość humanistycznych historii. Jako ludzie, przekonywałem, nie mamy dostępu do niezapośredniczonego doświadczenia owych innych form bycia człowiekiem, które poznajemy intelektualnie na poziomie abstrakcyjnym. Ludzie w swojej wewnętrznie zróżnicowanej wielości, ludzie jako gatunek i jako sprawcy antropocenu stanowią trzy powiązane, lecz analitycznie odrębne kategorie. Inaczej tworzymy ich archiwa i różnych używamy metod treningu, umiejętności badawczych, narzędzi i strategii analitycznych, aby zdać sprawę z ich historycznej sprawczości - i jest to w każdym przypadku sprawczość odmiennego rodzaju ${ }^{48}$.

Świadome połączenie tych chronologii o różnych skalach wywołało we mnie emocję, którą lubię porównywać do uczucia spadania. To było tak,

47 Polski przekład: Klimat historii. Cztery tezy, przeł. M. Szcześniak, „Teksty Drugie” 2014 nr 5 , S. 168-199 - przyp. tłum.

48 Zob. mój esej Postcolonial studies and the challenge of climate change w mojej książce The crises of civilization: exploring global and planetary histories, Oxford University Press, New Delhi 2018, S. $223-243$. 
jakbym, będąc humanistycznym historykiem zainteresowanym politycznymi kwestiami praw, sprawiedliwości i demokracji, spadł w otchłań „głębokiej” historii, głębokiego czasu geologicznego. Ów upadek w „głęboką" historię niesie ze sobą szok związany z rozpoznaniem inności planety i jej wielkoskalowych procesów czasoprzestrzennych, których częścią nieświadomie stali się ludzie. Pochodząc z subkontynentu indyjskiego, gdzie cukrzyca przybrała rozmiary epidemii, czasami wyjaśniam to doświadczenie, odwołując się do analogii z tym, jak poczucie własnej przeszłości momentalnie poszerza się u osoby, u której zdiagnozowano cukrzycę. Przed wizytą u lekarza miała ona (potencjalnie) historyczną wizję własnej przeszłości, biografię osadzoną w określonym kontekście społeczno-historycznym, obejmującą dwa lub trzy pokolenia. Natomiast diagnoza otwiera na zupełnie nową, bezosobową i długoterminową przeszłość, której nie można posiąść w sensie określonym kiedyś przez znakomitego teoretyka polityki C.B. Macphersona mianem „indywidualizmu właścicielskiego"49. Mieszkaniec subkontynentu usłyszy zapewne, że jego genetyczna skłonność do cukrzycy może być skutkiem stosowania diety opartej na ryżu (od co najmniej kilku tysięcy lat). Jeśli na dodatek jest pracownikiem uczelni i wywodzi się z rodziny bramińskiej lub innej wysokiej kasty, to nie bez znaczenia będzie praktykowanie siedzącego trybu życia od co najmniej kilku stuleci, i zapewne zostanie mu wyjaśnione, że zdolność ludzkich mięśni do zatrzymywania i uwalniania cukru wiąże się z faktem, iż ludzie prowadzili zbieracko-łowiecki sposób życia przez przytłaczającą część swej historii - ewolucja i głęboka historia! ${ }^{50}$ Żadna z tych dłuższych historii nie jest nam dostępna w doświadczeniu, ale nagle wpadamy w świadomość ich istnienia.

Chociaż mój esej z 2009 roku spotkał się z licznymi wyrazami uznania, wywołał też burzę krytyki. Krytycy zarzucali mi, że odniesienie do ludzi jako "gatunku dominującego" oraz użycie określenia „,antropocen” (a nie np. „kapitałocen") groziło „odpolitycznieniem" zmiany klimatu przez odwrócenie uwagi od kwestii odpowiedzialności, roli kapitalizmu, imperiów, nierównego rozwoju i popędu kapitalistycznej akumulacji. To bogaci, jak trafnie

49 Zob. C.B. Macpherson The theory of possessive individualism: Hobbes to Locke, Clarendon, Oxford 1962.

Archeolożka Kathleen D. Morrison stwierdza, że "kodyfikację elitarnych praktyk kulinarnych opartych na plonach z upraw nawadnianych, zwłaszcza ryżu" można udokumentować od "pierwszego tysiąclecia n.e. w południowych Indiach". Zob. K.D. Morrison The human face of the land: why the past matters for India's environmental future, NMML Occasional Paper, History and Society, New Series, nr 27, Nehru Memorial Museum and Library, New Delhi 2013, s. 16. 
wskazywano, są w znacznie większym stopniu odpowiedzialni za kryzys klimatyczny i zawsze mniej narażeni na skutki kryzysu niż biedni. Na część z tych głosów krytycznych odpowiedziałem w innym miejscu ${ }^{51}$. Bez wchodzenia w szczegóły pozwolę sobie po prostu napisać, że zgadzam się z niedawną opinią badacza literatury Gillena D’Arcy'ego Wooda, iż niektóre z zarzutów mogły się opierać na nieporozumieniu ${ }^{52}$.

Ogień krytyki, jaka na mnie spadła, mówi też coś o najnowszej historii dyscyplin interpretatywnych w naukach społecznych. Uczeni zajmujący się historią i teorią postkolonialną względnie późno odnotowali kryzys globalnego ocieplenia, mimo że wiedza naukowa na ten temat już w późnych latach 8o. przebijała się do mediów. Weźmy rok 1988. To właśnie wtedy James Hansen, ówczesny szef Centrum Lotów Kosmicznych im. Goddarda przy NASA, wystąpił przed Senatem Stanów Zjednoczonych, informując o trzech głównych konkluzjach: „Po pierwsze, ziemia jest cieplejsza w roku 1988 niż kiedykolwiek w historii pomiarów za pomocą przyrządów. Po drugie, globalne ocieplenie jest dziś dość silne, byśmy z dużym zaufaniem mogli go powiązać w relację przyczynowo-skutkową z efektem cieplarnianym. I po trzecie, nasze komputerowe symulacje klimatyczne sugerują,

51 Whose anthropocene? Revisiting Dipesh Chakrabarty's "Four theses”, ed. by R. Emmett, T. Lekan, wydanie specjalne "Transformations in Environment and Society" 2016 no. 2; mój esej The politics of climate is more than the politics of capitalism, "Theory, Culture, Society" 2017 vol. 34, no. 2/3, s. 1-13. Jeśli chodzi o feministyczną krytykę mojego stanowiska wyrażonego w pierwotnej wersji eseju Klimat historii, polecam Anthropocene feminism, ed. by R. Grusin, University of Minnesota Press, Minneapolis 2017, zwłaszcza wstęp Richarda Grusina oraz eseje Claire Colebrook i Stacy Alaimo. Zob. też T. Cohen, C. Colebrook Vortices: On "Critical Climate Change” as a Project, "South Atlantic Quarterly” 2017 vol. 116, no. 1, s. 129-143. Jedną z najnowszych krytyk mojego stanowiska można znaleźć w: D. Boscov-Ellen Whose universal? Dipesh Chakrabarty and the anthropocene ,"Capitalism, Nature, Socialism" 2020 vol. 31, no. 1, s. 70-83, https://www. tandfonline.com/doi/abs/10.1080/10455752.2018.151406o?journalCode=rcns20. Najbardziej jak dotąd solidną, życzliwą, ale zarazem stanowczą krytykę moich prac na temat zmiany klimatu można znaleźć w: I. Baucom History $4^{\circ}$ Celsius: search for a method in the age of the anthropocene, Duke University Press, Durham 2020.

"W swoim [...] artykule Klimat historii z 2009 r.", pisze Wood , „Dipesh Chakrabarty przekonywał, że geologiczna skala zmiany klimatu zmienia podstawowe terminy krytyki. [...] Zgodnie z jego teorią zmiana klimatu domaga się rozpoznania ludzkiej sprawczości na poziomie gatunkowym i odwołania się do «głębokiego czasu» w objaśnianiu historii świata. Idąc dalej, Chakrabarty upierał się zarówno przy subtelnych rozróżnieniach historycznych, jak i przy planetarnej świadomości głębokiego czasu, tymczasem jego krytycy [...] potraktowali jego argumentację karykaturalnie, jakby chodziło o binarną opozycję i rozłączną alternatywę między «krytyką» a «nauką»". G. D'Arcy Wood Climate delusion: hurricane Sandy, sea level rise, and 1840 s catastrophism, „Humanities" 2019 vol. 8, no. 131, s. 3-4. 
że efekt cieplarniany jest już dostatecznie mocny, aby wpływać na prawdopodobieństwo zjawisk ekstremalnych, takich jak letnie fale upałów"53. W tym samym roku przy ONZ powołano Międzyrządowy Zespół ds. Zmian Klimatu (IPCC).

Myśl i krytyka postkolonialna - nurt humanistyki o głębokim wpływie na teorię krytyczną pod koniec XX wieku - rozpoczęła swą podróż dziesięć lat wcześniej, wraz z ukazaniem się w 1978 roku klasycznej książki Edwarda Saida Orientalizm ${ }^{54}$. Począwszy od lat 80 ., wiele nurtów myśli - krytyczna teoria rasy, krytyka feministyczna, krytyka anty- i postkolonialna, studia kulturowe i mniejszościowe - połączyło siły i uwolniło humanistykę od arystokratycznego temperamentu, który od wieków towarzyszył badaniu tekstów, retoryki, filologii, gramatyki, prozodii itp. ${ }^{55}$ Humanistyka, dawniej gałąź wiedzy służąca kształceniu kulturalnych osób i legitymizacji kulturowych roszczeń do rządzenia wysuwanych przez elity imperialne i inne, przekształciła się w tych dekadach w dziedzinę zajmującą się badaniem i zarazem wytwarzaniem tego, co James Scott określił niezapomnianym mianem "broni słabych"56. Publikowane od 1982 roku „Subaltern Studies" były w znacznej mierze pomyślane w ramach tej nowej orientacji w humanistyce ${ }^{57}$. W 1988 roku Gayatri Chakravorty Spivak ogłosiła swój słynny esej Czy podporządkowani inni moga przemówić? ${ }^{58}$. Kilka lat później, w 1995 roku, Homi Bhabha, Stuart Hall, Kobena Mercer i inni wspólnie wystąpili jako kuratorzy pierwszej postkolonialnej wystawy i konferencji poświęconej

53 https://www.sealevel.info/1988_Hansen_Senate_Testimony.html.

E. Said Orientalizm, przeł. M. Wyrwas-Wiśniewska, Zysk i S-ka, Poznań 2018.

55 W kwestii opisu tego, jak dawniej pojmowano humanistykę w amerykańskim świecie akademickim, zob. I. Babbit Literature and the American college: in defense of the humanities, Houghton, Mifflin, Boston 1908. Por. też mój esej An anti-colonial history of postcolonial thought: a tribute to Greg Dening w książce Crises of civilization, s. 28-53, a także niektóre inne eseje z tej samej książki, dające pewną orientację odnośnie do przeobrażenia humanistyki w drugiej połowie XX wieku.

56 J.C. Scott Weapons of the weak: everyday forms of peasant resistance, Yale University Press, New Haven 1985.

57 Pierwszy tom ukazał się w 1982 roku: Subaltern studies: writings on Indian history and society, ed. by R. Guha, Oxford University Press, New Delhi 1982.

Omówienie historii i kontekstu tego eseju zob. Reflections on the history of an idea: Can the subaltern speak?, ed. by R.C. Morris, Columbia University Press, New York 2010. [Jego polski przekład: G.C. Spivak Czy podporzq̨dkowani inni moga przemówić?, przeł. E. Majewska, „Krytyka Polityczna" 2010 nr 24/25, s. 196-239 - przyp. tłum.]. 
Franzowi Fanonowi, która zaowocowała publikacją The fact of blackness ${ }^{59}$. Klasyczna już kolekcja postkolonialnych esejów Bhabhy, Miejsca kultury, ukazała się w 1994 roku $^{60}$.

Plonem tych nowych kierunków w humanistyce były imponujące diagnozy intelektualne, pozostawały one jednak, że pozwolę sobie na niezbyt zręczne wyrażenie, ekologicznie ślepe. Jeśli ta ocena wyda się komuś przesadna, wyjaśniam, o co mi chodzi. Od końca lat 6o. i przez całe lata 70. w różnych częściach świata obserwowaliśmy gwałtowny przypływ ruchów ekologicznych. W Europie zaczęły się pojawiać partie zielonych i zielona polityka. W wielu przypadkach aktywizm i refleksja ekologiczna prowadziły do krytyki kapitalistycznych modeli wzrostu (jak to widać w pismach znanej indyjskiej ekolożki Vandany Shivy). Alarm, jaki wszczęła Rachel Carson opublikowaną w 1962 roku książką Milcząca wiosna, w nie mniejszym stopniu niż obraz Ziemi jako „błękitnej planety”, spopularyzowany przez amerykańskich astronautów w 1972 roku, przyczynił się do zrodzenia idei, że ludzie mają ten „jeden świat" - jedną atmosferę, jedną wielką masę wód oceanicznych, jeden kulisty dom - zarazem skończony i kruchy, wystawiony na drapieżność kapitalizmu wydobywczego i poprzemysłowego stylu życia. Do czołowych przedstawień tej wizji „skończonej ziemi” należał opublikowany w 1972 roku raport Klubu Rzymskiego Granice wzrostu, autorstwa Donelli i Dennisa Meadowsów oraz ich kolegów ${ }^{61}$.

Jednak idea „jednego świata” nieszczególnie współbrzmiała z tradycją humanistyczną, z której wyrastała krytyka postkolonialna. Akademiccy humaniści (do których zaliczam też przedstawicieli interpretatywnych nurtów historii i antropologii) zasadniczo byli raczej „traczami” niż „tkaczami” ludzkiej historii. Wszelkie roszczenia do „jedności” świata należało ich zdaniem radykalnie prześwietlić, odnosząc je do realiów tego wszystkiego, co rzeczywiście dzieliło ludzi i tworzyło bazę rozmaitych reżimów ucisku, takich jak kolonializm, rasa, klasa, płeć, seksualność, ideologie, interesy. Byli więc sceptyczni wobec argumentów na rzecz owinięcia całego zróżnicowania ludzkich światów w jedność skończonej Ziemi. Taki ujednolicający ruch wydawał im się ideologicznie podejrzany, gdyż zawsze dotąd służył interesom władzy. Uczeni ci wierzyli, że drogę do emancypacji wszystkich ludzi można odnaleźć

59 The fact of blackness: Frantz Fanon and visual representation, ed. by A. Reed, Institute of Contemporary Arts i Bay Press, London-Seattle 1996.

60 H.K. Bhabha Miejsca kultury, przeł. T. Dobrogoszcz, Wydawnictwo UJ, Kraków 2010.

61 D. Meadows i in. Granice wzrostu, przeł. W. Rączkowska, S. Rączkowski, PWE, Warszawa 1973. 
jedynie wówczas, gdy najpierw zajmiemy się konfliktami i niesprawiedliwością wpisanymi we wspomniane podziały i je przepracujemy. W rzeczy samej podział na zwolenników „jednego świata" i zwolenników spojrzenia postkolonialnego, na „tkaczy” $i$,traczy”, można zaobserwować w wielu prawomocnych żądaniach, wysuwanych obecnie w imię sprawiedliwości ekologicznej bądź klimatycznej ${ }^{62}$. Ów odruch rozdrabniania jest dziś osadzony głęboko i całkowicie zrozumiały. Ostatecznie od ponad pięciu dekad - i z dobrych powodów - humaniści byli wychowywani w duchu skrajnej podejrzliwości wobec wszelkich roszczeń do totalności i uniwersalizmu. Ja sam byłem dzieckiem tej tradycji.

Zważywszy na to napięcie między „tractwem” $i$ „tkactwem”, w które moje własne myślenie również się ongiś wpisywało, ostatnich dziesięć lat poświęciłem na próby wypracowania własnej ścieżki uporania się z konsekwencjami przemyśleń wyrażonych w tekście Klimat historii.Cztery tezy i z kontrowersjami, jakie owe tezy wzbudziły. Dlatego mimo wszelkich dyskusji i całej krytyki, jaką na mnie ściągnął, esej ten - w zrewidowanej formie i pod zmienionym tytułem, Cztery tezy - pozostaje nieuniknionym punktem wyjścia tego projektu i oczywistym pierwszym rozdziałem niniejszej książki. Dodałem do niego zwięzły aneks, aby doprecyzować użycie przeze mnie takich wyrażeń, jak "gatunek" czy „negatywna historia uniwersalna”, które wzburzyły niektórych czytelników pierwotnej wersji tekstu.

Z metodologicznego punktu widzenia książka prezentuje moje rozumowanie i wnioski, prowadząc czytelnika ścieżką, którą ja sam podążałem podczas swoich dociekań. Przełomowym odkryciem było dla mnie nagłe uświadomienie sobie, że pojęcie globu w słowie "globalizacja” nie jest tym samym, co w wyrażeniu "globalne ocieplenie". To samo słowo, ale odmienne desygnaty. Owo spostrzeżenie doprowadziło mnie do rozróżnienia globu i planety. Nie chodzi o binarną opozycję, co pragnę podkreślić, lecz o dwa powiązane terminy odróżnione od siebie analitycznie. Im więcej czytałem prac naukowych badaczy systemu Ziemi i im więcej rozmyślałem nad oskarżeniami, że moje cztery tezy oznaczały rozgrzeszanie kapitalizmu, tym bardziej to rozróżnienie wydawało mi się niezbędne. Tego właśnie dotyczy

62 Klasycznym tekstem jest: A. Agarwal, S. Narain Global warming in an unequal world: a case of environmental colonialism, Centre for Science and Environment, New Delhi 1991. Z kolei książka Roba Nixona Slow violence and the environmentalism of the poor (Harvard University Press, Cambridge 2011) cieszy się zasłużoną reputacją jako przykład postkolonialnej humanistyki traktującej łącznie problemy nierówności między ludźmi i degradacji środowiska spowodowane działalnością kapitalistycznych przedsiębiorstw. 
cała pierwsza część książki. W rozdziale drugim, zatytułowanym „Połączone historie”, przyglądam się wstępnie temu, dlaczego sięgająca kilka wieków wstecz historia kapitalizmu nie daje nam wystarczającego oparcia intelektualnego do zmierzenia się z obnażonymi przez antropogeniczną zmianę klimatu problemami ludzkiej historii. W rozdziale tym przygotowuję grunt pod rozróżnienie globu i planety, które jest dogłębnie omówione w rozdziale trzecim, „Planeta jako kategoria humanistyki”. Tam znajduje się intelektualny punkt oparcia, wokół którego obraca się moja książka. Kategoria „planety” pozwoliła mi dostrzec, a w końcu także powiedzieć, że refleksja nad naszą epoką wymaga od nas spojrzenia na samych siebie równocześnie z dwóch perspektyw: planetarnej i globalnej. Podczas gdy glob jest konstruktem humanocentrycznym, planeta decentruje to, co ludzkie.

Druga część książki, zatytułowana "Dlaczego trudno być nowoczesnym”, składa się z trzech rozdziałów, w których na różne sposoby przyglądam się, dlaczego nowoczesne idee wolności - czy to indywidualnej, czy narodowej, czy mającej obejmować całą ludzkość - zachowują nadal powab, mimo że wiele spośród stojących za nimi przesłanek zostało słusznie zakwestionowanych przez rozmaitych krytyków nowoczesności i modernizacji. W otwierającym tę część rozdziale czwartym („Dlaczego trudno być nowoczesnym”) analizuję intymny związek zachodzący w państwach postkolonialnych między ich koncepcjami wolności a zwiększonym zapotrzebowaniem na energię, które historycznie było zaspokajane głównie przez paliwa kopalne i różne projekty „panowania nad przyrodą” (np. budowanie zapór na rzekach). Kolejny (piąty) rozdział, „Planetarne aspiracje: jak czytać samobójstwo w Indiach”, to odczytanie idei ludzkości i wolności zapisanych w liście samobójczym przez młodego mężczyznę identyfikującego się jako dalit, który odebrał sobie życie w 2016 roku. Interpretacja historii piętna i okazywanego przez wyższe kasty obrzydzenia wobec „ciała pariasa” wskazuje na pewne granice wyobrażeń ludzkiego ciała w panujących koncepcjach tego, co polityczne. Zamykający tę część rozdział szósty, będący sprawozdaniem z lektury rozprawki Immanuela Kanta z 1786 roku zatytułowanej Przypuszczalny początek ludzkiej historii, to w gruncie rzeczy krytyka - w perspektywie antropocenu - fundamentalnego dla nowoczesności rozróżnienia moralnej i zwierzęcej egzystencji ludzi. Rozróżnienie to, poczynione przez wielkiego filozofa, w sytuacji dzisiejszego kryzysu biosfery okazuje się coraz trudniejsze do utrzymania.

Ostatnią część książki nazwałem „Mierząc się z tym, co planetarne”, po trosze w wyrazie uznania dla książki teoretyka polityki Williama Connolly'ego o tym samym tytule. Rozpoczyna ją rozdział „Czas antropocenu” (rozdz. 7), 
w którym próbuję objaśnić to, co geolog Jan Zalasiewicz nazywa planetocentrycznym sposobem myślenia, odróżniając go od refleksji stawiającej w centrum wyłącznie ludzkie problemy. Następnie w rozdziale „W stronę antropologicznego prześwitu" (rozdz. 8) pogłębiam niektóre z konsekwencji, jakie nasze niedawne otwarcie na wymiar planetarny i geologiczny niesie dla naszego pojmowania kondycji ludzkiej dziś. Na obecny kryzys patrzę jako na okazję do pracy nad tym, co Karl Jaspers nazywał „świadomością epokową", formą argumentacji nastawionej na przygotowanie gruntu pojęciowego do przemyślenia kondycji ludzkiej, zanim zaangażujemy się w jakąś konkretną wersję praktyki politycznej czy aktywizmu. Faktyczność planety - kategorii objaśnionej w części pierwszej - wkraczająca w codzienne doświadczenie ludzi zmusza do zapytania, czy wiążącą ludzi i ziemię/świat relację wzajemności, którą wielu XX-wiecznych myślicieli odziedziczyło, przyjmowało za oczywistość i celebrowało, można dziś w ogóle podtrzymać. Jaką w obliczu aktualnego kryzysu ekologicznego pójdziemy drogą w stronę stworzenia nowych „dóbr wspólnych", nowej antropologii, by tak rzec, w poszukiwaniu redefinicji ludzkiej relacji z tym, co pozaludzkie, włączając w to planetę? Tak kończy się ta książka - zaczątkami, mam nadzieję, konkluzji jeszcze nieosiągniętej przez historię.

Jako postscriptum posłużyła mi rozmowa z Brunonem Latourem, w której zostało poruszonych wiele wątków przewijających się w książce.

Jak widać z powyższego opisu, moje ujęcie ludzkich światów i ich relacji z planetą, którą ludzie zamieszkują, nie ma na celu przykładać się w bezpośrednim i praktycznym znaczeniu do możliwych rozwiązań konfliktów klimatycznych na świecie. Konflikty te, jak wskazuję, mogą wręcz się zaostrzyć wskutek planetarnego kryzysu ekologicznego i wywoływanych przezeń rozmaitych napięć - dotyczących granic, wody, żywności czy mieszkań. Mam nadzieję, że opowieści, w których nasza głęboka historia spotyka się z historiami zapisanymi, pomogą w uzyskaniu nowych perspektyw patrzenia na owe konflikty, a tym samym pośrednio przyczynią się do ich złagodzenia. Im bardziej widzimy, że na przekór wszelkim podziałom i nierównościom stawką jest dziś przetrwanie cywilizacji w znanym nam kształcie, tym wyraźniej, mam nadzieję, dostrzeżemy niewystarczalność naszych nieuchronnie stronniczych pomysłów na zajęcie się tym, co z lekkim ukłonem w stronę Arendt nazwać można kondycją ludzką dziś.

W książce o antropocenie filozof Sverre Raffnsøe przypomina nam, że w swym wprowadzeniu do logiki Kant podał cztery pytania decydujące o rozróżnieniu czterech dziedzin poznania. Podstawowym pytaniem „poznania, 
nauki, teorii i metafizyki” jest „Co mogę wiedzieć?”, podstawowym pytaniem myśli moralnej i praktycznej - „Co powinienem czynić?”, w kontekstach religijnych i estetycznych zaś - „Na co wolno mi mieć nadzieję?”. Raffnsøe wskazuje następnie, że zdaniem Kanta owe trzy podstawowe pytania „są ze sobą ściśle powiązane, a przy tym wzajemnie wspierają i są oświetlane przez [...] czwarte i zasadnicze pytanie: «Czym jest człowiek? [Was ist der Mensch?]»"63. To ostatnie pytanie, twierdził Kant, jest domeną „antropologii”64. Zjawisko antropocenu i kryzys zmiany klimatu zmuszają nas do zadania wszystkich tych pytań. Naukowcy, w tym zajmujący się naukami społecznymi, mają najlepsze predyspozycje do ustalania tego, co możemy wiedzieć. Politycy, aktywiści, twórcy polityki publicznej i inżynierowie są przygotowani, by odkryć, co możemy czynić. Religii, estetyce i pokrewnym dziedzinom myśli pozostaje wskazanie, na co wolno nam mieć nadzieję. Kłopotliwe położenie, w jakim znalazła się dziś ludzkość, stawia przed humanistą ponownie pytanie o ludzką kondycję. Niniejsza książka jest więc skromnym wkładem w kolektywny wysiłek humanistów nastawionych na przemyślenie naszej drogi ku nowej filozoficznej antropologii.

Przeł. Adam Ostolski

63 S. Raffnsøe Philosophy of the anthropocene, Palgrave Macmillan, Houndmills 2016, s. 53 przyp. 1.

64 I. Kant Logika: podręcznik do wykładów, przeł. A. Banaszkiewicz, słowo/obraz terytoria, Gdańsk 2005 , s. 37. Pytania te towarzyszyły Kantowi jeszcze długo. Zob. I. Kant Krytyka czystego rozumu, t. 2, przeł. R. Ingarden, PWN, Warszawa 1957, s. 548-550 (A805/B833; A806/B834). 


\section{Abstract}

\section{Dipesh Chakrabarty}

UNIVERSITY OF CHICAGO

Intimations of the Planetary

In this Introduction to his book The Climate of History in a Planetary Age (2021) Chakrabarty explores how climate change and discussions on the anthropocene impact the writing of history as well as our notions of being political. He argues that in an era of climate change the global history of divided humanity, which is possible to grasp through concepts such as capitalism, colonialism or globalisation, becomes intertwined with the planetary "deep history" of humans as a species. As a result, the conceptual framework related to postcolonial theory and critiques of capitalism cease to suffice; historiography must begin to also reference the findings of biology and geology. This also forces us to look afresh at what it is to be political, looking back at the work of Hannah Arendt, Carl Schmitt and Bruno Latour.

\section{Keywords}

postcolonial theory, capitalism, globalisation, anthropocene, climate change, environmental history 